\title{
IMPROVING ABILITY TO KNOW LETTERS THROUGH MOVEMENT AND SONG VIDEO SHOWS OF 4-5 YEARS OLD
}

\author{
Siti Khodijah'), Siti Wahyuningsih' ${ }^{2)}$, Upik Elok Endang Rasmani ${ }^{3)}$ \\ Program Studi PG-PAUD Universitas Sebelas Maret \\ khodijah903@student.uns.ac.id
}

\begin{abstract}
This study aimed to improve the ability to recognize letters in children aged 4-5 years through motion video and song. The type of this study was a classroom action research were conducted in two cycles. Data collection techniques used observation, interviews, test, and documentation. Quantitative data analysis techniques used comparative data analysis, and qualitative data analysis used interactive model analysis. The validity of quantitative data used construct validity, while the validity test of qualitative data using triangulation and triangulation techniques. The results showed there is an increased ability to recognize letters that can be viewed through an increase in the percentage of completeness that in the first cycle of $65 \%$ and the second cycle by $82 \%$. The increase was evidenced by the child's success in imitating / create form letters b,d,p,q,l,i, pronounce letter sounds b,d,p,q,l,i and distinguish the shape of the letter $b$ and $d, p$ and $q, 1$ and $i$. The conclusion of this study is the impression of motion video and song can improve the ability to recognize letters in children aged 4-5 years.
\end{abstract}

Keywords: recognize letters, video, song and movement, children aged 4-5 years

\section{MENINGKATKAN KEMAMPUAN MENGENAL HURUF MELALUI TAYANGAN VIDEO GERAK DAN LAGU PADA ANAK USIA 4-5 TAHUN}

\begin{abstract}
Abstrak: Penelitian ini memiliki tujuan untuk meningkatkan kemampuan mengenal huruf pada anak usia 4-5 tahun melaluitayangan video gerak dan lagu. Jenis penelitian ini termasuk dalam Penelitian Tindakan Kelas yang dilaksanakan dalam dua siklus. Teknik pengumpulan data yang dipakai yaitu observasi, wawancara, tes, dan dokumentasi. Teknik analisis data kuantitatif memakai analisis data komparatif, sedangkan analisis data kualitatif menggunakan analisis model interaktif. Uji validitas data kuantitatif menggunakan validitas konstruk, sedangkan uji validitas data kualitatif menggunakan triangulasi sumber dan triangulasi teknik. Hasil penelitian menunjukkan terdapat peningkatan dalam kemampuan mengenal huruf diperlihatkan melalui peningkatan persentase ketuntasan yaitu pada siklus I sebesar $65 \%$ dan siklus II sebesar $82 \%$. Peningkatan tersebut dibuktikan dengan keberhasilan anak dalam meniru/membuat bentuk huruf b,d,p,q,l,i, menyebutkan bunyi huruf b,d,p,q,l,i dan membedakan bentuk huruf $b$ dan $d, p$ dan $q, 1$ dan i. Kesimpulan hasil penelitian ini adalah tayangan video gerak dan lagu dapat meningkatkan kemampuan mengenal huruf pada anak-anak usia 4-5 tahun.
\end{abstract}

Kata Kunci: mengenal huruf, video, gerak dan lagu, anak usia 4-5 tahun

\section{PENDAHULUAN}

Kemampuan mengenal huruf merupakan salah satu perkembangan bahasa. Seefeldt dan Wasik (2008) [1] menjelaskan bahwa kemampuan mengenal huruf adalah kemampuan seorang anak dalam mengenal ciri-ciri aksara dalam tulisan yang termasuk anggota abjad untuk melambangkan bunyi bahasa. Kemampuan mengenal huruf sangat penting bagi anak, karena berkaitan dengan kemampuan membaca. Hal tersebut sejalan dengan pendapat Ecalle (2008) [2] dalam penelitiannya bahwa kemampuan anak dalam mengenal huruf dapat dijadikan sebagai pembelajaran terbaik dalam membaca dan mengeja untuk masuk jenjang yang akan datang. Lebih lanjut, Zaenab (Anjelina, 2017) [3] memaparkan bahwa kemampuan 
mengenal huruf adalah kemampuan anak dalam menyebutkan bunyi dan nama pada setiap huruf-huruf abjad.

Peraturan Menteri Pendidikan dan Kebudayaan RI No.137 tahun 2014 [4] tentang Standar Nasional PAUD memaparkan bahwa tingkat pencapaian perkembangan anak usia 4-5 tahun dikatakan dapat mengenal huruf dengan baik apabila dapat mencapai indikator meniru (menuliskan dan mengucapkan) huruf A-Z. Selain itu Jones, Clark, \& Reutzel (2012) [5] dalam penelitiannya memaparkan bahwa pengetahuan anak usia dini dalam mengenal huruf alfabet ditekankan pada kemampuan menyebutkan nama dan bunyi huruf, membedakan masing-masing huruf, dan membuat bentuk huruf. Berdasarkan pendapat di atas maka indikator kemampuan mengenal huruf anak usia 4-5 tahun yang diadaptasi dari Permendikbud No 137 Tahun 2014 [4] dan penelitian Jones, Clark, \& Reutzel (2012) [5] yaitu meniru/membuat bentuk huruf, menyebutkan bunyi huruf, dan membedakan bentuk huruf. Ketiga indikator tersebut akan digunakan untuk menentukan keberhasilan dalam penelitian ini.

Anak usia 4-5 tahun perlu diajarkan tentang pengenalan nama huruf, bentuk huruf, bunyi huruf (huruf vokal dan konsonan), pemahaman kosakata dan penggabungan huruf (vokal dan konsonan) (Bond, Blachman \& Muter, et al dalam Susanto, 2014) [6]. Abdurrahman (2003) [7] menyampaikan bahwa huruf konsonan yang mulai dipelajari anak yaitu $b, d, k$, $1, \mathrm{~m}, \mathrm{n}$, dan s serta huruf vokal yaitu a, i, u, e, o. Seefeldt dan Wasik (2008) [1] menjelaskan bahwa anak prasekolah dalam mempelajari huruf mereka memulai dengan mencirikan bentuk huruf, seperti huruf yang memiliki ciri garis lurus yaitu " $i$ " atau lengkung baik terbuka atau tertutup yaitu "c" dan "o". Namun dalam mempelajari huruf anak-anak masih mengalami kesulitan. Sejalan dengan pendapat Bowles (2014) [8] bahwa huruf-huruf kecil yang memiliki kemiripan visual sangat membingungkan anak seperti $b$ dan $d$ serta $p$ dan $q$ yang merupakan bayangan cermin satu sama lain dan huruf 1 secara visual serupa dengan angka 1 .

Berdasarkan hasil pratindakan yang dilakukan di kelompok A TK Sri Juwita Hanum Surakarta tanggal 8-9 Januari 2019, melalui pretest didapatkan hasil dari 17 anak terdapat 7 anak (41\%) yang menunjukkan nilai kemampuan mengenal huruf sudah tuntas. Namun sebanyak 10 anak (59\%) menunjukkan nilai kemampuan mengenal huruf tidak tuntas. Berdasarkan hasil pretest dilakukan observasi, hasilnya menunjukkan ketika anak-anak diminta untuk menulis huruf "p" pada kata "polisi" dengan cara meniru, peneliti menemukan beberapa anak juga tidak mau mengerjakan sehingga dibantu oleh guru, ada anak yang juga tidak dapat menyebutkan nama huruf yang ada pada kata polisi, beberapa anak juga tidak dapat meniru tulisan " $p$ " pada kata polisi, beberapa anak yang terbalik dalam menyebutkan huruf "p" menjadi "q" dan belum dapat membedakan huruf "i" dan "l".

Rendahnya kemampuan mengenal huruf anak berdasarkan hasil observasi dan wawancara dengan guru kelompok A, diketahui karena pembelajaran terkait pengenalan huruf masih jarang diberikan pada anak. Selain itu, penggunaan alat atau media dalam 
pengenalan huruf baru memanfaatkan peralatan yang disediakan di sekolah seperti kartu dan balok huruf serta metode yang digunakan dalam pembelajaran pengenalan huruf masih terbatas pada mengenal huruf melalui permainan tebak huruf.

Berdasarkan permasalahan di atas, maka diperlukan upaya penyelesaian untuk meningkatkan kemampuan mengenal huruf melalui tayangan video gerak dan lagu. Riyana (Rahayu, 2017) [9] menjelaskan bahwa video adalah media yang menampilkan suatu materi secara audio dan visual berisi konten-konten seperti prosedur, prinsip, konsep atau pengetahuan untuk membantu seseorang dalam memahami suatu materi pembelajaran. Sedangkan Prastowo (2014) [10] menyatakan bahwa video adalah media audiovisual yang mengkombinasikan dua materi yaitu visual untuk merangsang indera penglihatan dan auditif untuk merangsang indera pendengaran.

Video dapat menyampaikan suatu materi yang berisi animasi bergerak dengan suara yang menyertainya. Selain itu video biasanya berisi suatu konten atau materi yang mengarah pada pembelajaran kognitif, bahasa, afektif, motorik, interpersonal dan perkembangan lainnya (Smaldino, dkk., 2012) [11]. Prastowo (2014) [10] menambahkan bahwa video dapat dimanfaatkan dalam program pembelajaran, karena melalui video anak dapat melihat gambar bergerak yang dilengkapi dengan suara yang menyertainya. Anak-anak dalam hal ini berada pada fase meniru sehingga jika terdapat video, anak akan lebih mudah meniru dan mempelajari objek yang ada pada tayangan video.

Penggunaan tayangan video gerak dan lagu dalam pembelajaran di
PAUD harus memperhatikan karakteristik anak. Materi pembelajaran dalam tayangan video harus dikemas secara menarik dan menyenangkan bagi anak. Salah satu isi konten yang tepat pada tayangan video dalam pengenalan huruf pada anak yaitu gerak dan lagu. Gerak dan lagu merupakan kegiatan yang menyenangkan, karena anak diajak untuk bergerak sambil bernyanyi mengikuti iringan musik. Gerak dan lagu adalah kegiatan bergerak, mendengarkan lagu sambil bernyanyi untuk meluapkan emosi diri (Taylor dkk., 2012) [12]. Selain itu, gerak dan lagu juga bermanfaat untuk mengembangkan imajinasi, kreativitas, dan kegembiraan pada anak (Volchegorskaya \& Nogina, 2014) [13].

Melalui tayangan video gerak dan lagu anak dapat mengembangkan perkembangan fisik motorik, kogitif, khususnya perkembangan bahasa yaitu mengenal huruf. Shin (2014) [14] menyatakan bahwa salah satu manfaat melakukan kegiatan bergerak sambil bernyanyi dapat meningkatkan bahasa anak dalam hal keaksaraan.

\section{METODE PENELITIAN}

Penelitian ini merupakan Penelitian Tindakan Kelas (Classroom Action Research) model Kemmis \& Mc Taggart dengan pendekatan data kualitatif dan kuantitatif (Tampubolon, 2014) [15]. Penelitian ini dilaksanakan selama dua siklus, setiap siklus terdapat dua pertemuan meliputi pelaksanaan, perencanaan dan pengamatan, serta refleksi. Penelitian ini dilaksanakan di TK Sri Juwita Hanum Surakarta. Subjek dalam penelitian ini adalah anak kelompok A yaitu kelompok anak usia 4-5 tahun yang berjumlah 
17 anak, terdiri dari 6 anak laki-laki dan 11 anak perempuan.

Jenis data yang digunakan dalam penelitian ini adalah data kuantitatif yaitu data kemampuan mengenal huruf dari hasil unjuk kerja dan penugasan sedangkan data kualitatif yaitu nama anak, dokumentasi berupa foto dan video, hasil wawancara dengan guru kelas, dan catatan observasi selama pembelajaran. Sumber data dalam penelitian ini diperoleh dari guru kelompok A dan aktivitas pembelajaran sedangkan sumber data sekunder meliputi dokumen kependidikan, hasil penilaiananak kelompok A, dokumen berupa nama anak, video, foto kegiatan yang berhubungan dengan kemampuan mengenal huruf.

Teknik pengumpulan data yang digunakan dalam penelitian ini adalah observasi, wawancara, tes, dan dokumentasi. Teknik analisis data meliputi analisis data kuantitatif menggunakan analisis deskriptif komparatif, sedangkan analisis data kualitatif menggunakan model interaktif Miles dan Huberman meliputi pengumpulan data, reduksi data, penyajian data dan penarikan kesimpulan (Sugiyono, 2015) [16]. Teknik uji validitas data kuantitatif menggunakan validitas konstruk, sedangkan uji validitas data kualitatif menggunakan triangulasi sumber dan triangulasi teknik.

Indikator yang digunakan dalam penelitian ini yaitu 1) meniru/membuat bentuk huruf b,d,p,q,1,i; 2) menyebutkan bunyi huruf b,d,p,q,1,i; 3) membedakan bentuk huruf $b$ dan $d, p$ dan $q, 1$ dan $i$. Indikator tersebut dapat dikatakan berhasil apabila hasil yang diperoleh minimal $75 \%$ dari jumlah anak yang dapat mencapai tingkat kemampuan sesuai indikator yang telah ditetapkan (Tampubolon, 2014) [15].

\section{HASIL DAN PEMBAHASAN}

Hasil penelitian menunjukkan, siklus I mendapatkan hasil sebesar $65 \%$ atau sebanyak 11 anak mendapat nilai tuntas, sedangkan sebesar $35 \%$ atau sebanyak 6 anak mendapat nilai tidak tuntas. Siklus II mendapatkan hasil sebesar $82 \%$ atau sebanyak 14 anak mendapatkan nilai tuntas, sedangkan sebesar $18 \%$ atau sebanyak 3 anak mendapat nilai tidak tuntas.

Hasil ketuntasan kemampuan mengenal huruf pada anak kelompok A dari pratindakan, siklus I, sampai siklus II disajikan dalam bentuk tabel 1 sebagai berikut:

Tabel 1. Data kemampuan mengenal huruf anak pra tindakan, siklus I, dan siklus II

\begin{tabular}{ccccccc}
\hline Ket & \multicolumn{2}{c}{$\begin{array}{c}\text { Pra } \\
\text { Tindakan }\end{array}$} & Siklus I & Siklus II \\
\cline { 2 - 7 } & $\mathrm{f}$ & $\%$ & $\mathrm{f}$ & $\%$ & $\mathrm{~F}$ & $\%$ \\
\hline Tuntas & 7 & 41 & 11 & 65 & 14 & 82 \\
\hline $\begin{array}{l}\text { Tidak } \\
\text { tuntas }\end{array}$ & 10 & 59 & 6 & 35 & 3 & 18 \\
\hline
\end{tabular}

Tabel 1 menunjukkan adanya peningkatan dari pra tindakan sampai siklus II. Peningkatan tersebut terjadi dengan ditandai meningkatnya nilai ketuntasan pada setiap indikator dari pratindakan, siklus I, sampai siklus II. Selain itu, anak sudah mampu dalam meniru/membuat bentuk huruf $\mathrm{b}, \mathrm{d}, \mathrm{p}, \mathrm{q}, 1, \mathrm{i}$, menyebutkan bunyi huruf $\mathrm{b}, \mathrm{d}, \mathrm{p}, \mathrm{q}, \mathrm{l}, \mathrm{i}$ dan membedakan bentuk huruf $b$ dan $d, p$ dan $q, 1$ dan i. Hal tersebut terlihat ketika anak dalam meniru/membuat bentuk huruf $\mathrm{b}, \mathrm{d}, \mathrm{p}, \mathrm{q}, 1, \mathrm{i}$, menyebutkan bunyi huruf $\mathrm{b}, \mathrm{d}, \mathrm{p}, \mathrm{q}, \mathrm{l}, \mathrm{i}$, dan membedakan bentuk huruf $\mathrm{b}$ dan $\mathrm{d}, \mathrm{p}$ dan $\mathrm{q}, 1$ dan i sudah tidak keliru, anak sudah tidak terbalik ketika meniru atau mebedakan huruf $b$ dengan $\mathrm{d}, \mathrm{p}$ atau $\mathrm{q}$ dan sebaliknya, serta huruf 1 dengan i. ketika anak menyebutkan bunyi huruf juga sama, anak-anak tidak keliru menyebutkan 
huruf $\mathrm{b}$ dengan $\mathrm{d}, \mathrm{p}$, atau $\mathrm{q}$ serta huruf 1 dengan $\mathrm{i}$.

Berikut adalah persentase ketuntasan kemampuan mengenal huruf anak setiap indikator per siklus pada tabel dibawah ini:

Tabel 2. Persentase Ketuntasan Kemampuan Mengenal Huruf Anak Setiap Indikator Per Siklus

\begin{tabular}{lccc}
\hline \multicolumn{1}{c}{ Indikator } & \multicolumn{3}{c}{ Persentase Ketuntasan } \\
\cline { 2 - 4 } & $\begin{array}{c}\text { Pra } \\
\text { Tindakan }\end{array}$ & $\begin{array}{c}\text { Siklus } \\
\text { I }\end{array}$ & $\begin{array}{c}\text { Siklus } \\
\text { II }\end{array}$ \\
\hline $\begin{array}{l}\text { Meniru/mem } \\
\text { buat bentuk } \\
\text { huruf }\end{array}$ & $47 \%$ & $71 \%$ & $88 \%$ \\
b,d,p,q,1,i & & & \\
\hline $\begin{array}{l}\text { Menyebutka } \\
\text { n bunyi huruf } \\
\text { b,d,p,q,1,i }\end{array}$ & $47 \%$ & $71 \%$ & $88 \%$ \\
\hline $\begin{array}{l}\text { Membedakan } \\
\text { bentuk huruf } \\
\text { b dan d, p } \\
\text { dan q, ldan i }\end{array}$ & $41 \%$ & $71 \%$ & $82 \%$ \\
\hline
\end{tabular}

Berdasarkan tabel 2 tersebut, dapat dijabarkan bahwa indikator meniru/membuat bentuk huruf b,d,p,q,l,i pada pratindakan sebesar $47 \%$, kemudian meningkat pada siklus I yaitu $71 \%$ dan meningkat kembali pada siklus II yaitu $88 \%$. Indikator mengucapkan bunyi huruf b,d,p,q,l,i pada pratindakan sebesar 47\%, kemudian meningkat pada siklus I yaitu $71 \%$ dan meningkat kembali pada siklus II yaitu $88 \%$. Indikator membedakan bentuk huruf $b$ dan $\mathrm{d}, \mathrm{p}$ dan $\mathrm{q}, 1$ dan i pada pratindakan sebesar $41 \%$, kemudian meningkat pada siklus I yaitu $71 \%$ dan pada siklus II meningkat kembali sebesar $82 \%$

Berdasarkan uraian tersebut maka dapat disimpulkan bahwa setiap indikator kemampuan mengenal huruf yang diterapkan pada anak menggunakan kegiatan gerak dan lagu melalui tayangan video mengalami peningkatan pada setiap siklusnya. Kemampuan mengenal huruf pada anak sebelum dilakukan tindakan yaitu anak belum mampu meniru/membuat bentuk huruf, menyebutkan bunyi huruf, dan membedakan bentuk huruf. Meskipun demikian masih terdapat beberapa anak yang belum tuntas dalam kemampuan mengenal huruf. Anak-anak yang belum tuntas berjumlah 3 anak. Tiga anak tersebut masih berkembang pada indikator membedakan bentuk huruf $b$ dan $d, p$ dan q, 1 dan i, dalam hal ini anak-anak tersebut hanya mampu membedakan 1 pasang bentuk huruf dari huruf $b$ dan d, p dan q, 1 dan i. Kondisi ini terjadi karena anak-anak tersebut masih mengalami kesulitan dalam membedakan bentuk huruf yang sama seperti $b$ dengan $p$ atau $d, p$ dengan $b$ atau q, dan 1 dengan i. Anak-anak tersebut dalam hal ini masih kebingungan dan terbalik dalam membedakan huruf $b$ dan $d, p$ dan $q, 1$ dan i. Sejalan dengan hal tersebut Bowles (2014) [8] memaparkan bahwa huruf-huruf kecil yang memiliki kemiripan visual sangat membingungkan anak seperti $\mathrm{b}$ dan $\mathrm{d}$ serta $\mathrm{p}$ dan $\mathrm{q}$ yang merupakan bayangan cermin satu sama lain dan huruf 1 secara visual serupa dengan angka 1 . Kesulitan yang dialami anak dalam membedakan bentuk huruf yaitu ketika mengidentifikasi dan mencetakkan huruf-huruf seperti d,b,p, dan q, karena keempat huruf tersebut dibuat dengan garis lurus dan bengkok (Beaty, 2013) [17].

Peneliti memberikan solusi pada anak yang belum meningkat kemampuan mengenal huruf menggunakan tayangan video gerak dan lagu. Peneliti memberikan pendampingan dan pengarahan selama pengenalan huruf melalui tayangan video gerak dan lagu. Pembelajaran menggunakan tayangan video dapat memotivasi anak untuk semangat dalam belajar dan anak lebih mudah mengingat materi 
pembelajaran. Sanaky (2015) [18] menjelaskan bahwa penggunaan tayangan video dalam pembelajaran dapat mengurangi kejenuhan anak dalam belajar sehingga dapat memotivasi anak untuk belajar karena sifat video yang audio visual serta menambah daya tahan ingatan anak tentang objek yang dipelajari anak.

Berdasarkan data-data dari pembahasan maka dapat disimpulkan bahwa penggunaan tayangan video gerak dan lagu dapat meningkatkan kemampuan mengenal huruf pada anakanak kelompok A.

\section{SIMPULAN}

Hasil penelitian ini menyatakan bahwa melalui tayangan video gerak dan lagu dapat meningkatkan kemampuan mengenal huruf pada anak-anak kelompok A.

Berdasarkan hasil penelitian saran peneliti bagi guru sebaiknya guru memperhatikan materi-materi pembelajaran yang ditampilkan pada tayangan video agar lebih menarik, sehingga anak akan tertarik memperhatikan tayangan video dan mudah menyerap materi yang disampaikan melalui tayangan video. Sedangkan saran bagi peneliti lain semoga hasil penelitian ini dapat digunakan sebagai bahan referensi untuk penelitian yang sejenis dengan penelitian ini dan dapat lebih mengembangkan penggunaan tayangan video gerak dan lagu yang telah diterapkan sebelumnya.

\section{DAFTAR PUSTAKA}

[1] Seefeldt, Carol dan Barbara A. Wasik. (2008). Pendidikan anak usia dini menyiapkan anak usia tiga, empat, dan lima tahun masuk sekolah. (P. Nasar, Terjemahan). Jakarta: PT. Indeks.

[2] Ecalle, J., Biot-Chevrier, C., \& Magnan, A. (2008). Alphabet knowledge and early literacy skills in french beginning readers. European Journal of Development Paychology,5, 303-325.

[3] Anjelina, B., Wusono I., \& Enda P. (2017). Pengaruh permainan jemuran kata terhadap kemampuan mengenal huruf pada anak usia 4-5 tahun di tk islam terpadu insan utama 2 kecamatan tampan kota pekanbaru. Jurnal Online Mahasiswa Fakultas Keguruan dan Ilmu Pendidikan Universitas Riau,4(1), 1-13.

[4] Kemendikbud. (2015). Peraturan menteri pendidikan dan kebudayaan nomor 137 tahun 2014 tentang standar nasional pendidikan anak usia dini. Jakarta: Kemendikbud.

[5] Jones, C. D., Clark, S. K., \& Reutzel D. R. (2012). Enchanging alphabet knowledge instruction: research implications and practical strategies for early childhood educators. Early Childhood Education J,6, 110.

[6] Susanto, A. (2014). Perkembangan anak usia dini: pengantar dalam berbagai aspeknya. Jakarta: Kencana Prenadamedia Group.

[7] Abdurrahman, M. (2003). Pendidikan bagi anak berkesulitan belajar. Jakarta: Rineka Cipta. 
[8] Bowles, R. P., dkk. (2014). Item respone analysis of uppercase and lowercase letter name knowledge. Journal of Psychoeducational Assesment,32(2), 146-156.

[9] Rahayu, S. (2017). Pengembangan bahasa pada anak usia dini. Yogyakarta: Kalimedia.

[10] Prastowo, A. (2014). Panduan kreatif membuat bahan ajar inovatif (menciptakan metode pembelajaran yang menarik dan menyenangkan). Yogyakarta: Diva Press.

[11] Smaldino, S., Lowther, D., \& Russell, J. (2012). Instructional technology and media for learning (teknologi pembelajaran dan media untuk belajar). (A. Rahman, Terjemahan). Jakarta: Kencana Prenada Media Group.

[12] Taylor, S., dkk. (2012). Music and movement for young children's healthy development. Dimensions of Early Childhood,40(2), 33-40.

[13] Volchegorskaya, E. \& Nogina, O. (2014). Musical Development in Early Childhood. Social and Behavioral Sciences,32 (2), 172-177.

[14] Shin, J. (2017). Get up and sing ! get up and move! using songs and movement with young learners of english. English Teaching Forum,55(2), 14-25.

[15] Tampubolon, S. (2014). Penelitian Tindakan Kelas Sebagai Pengembangan Profesi Pendidik dan Keilmuan. Jakarta: Erlangga.
[16] Sugiyono. (2017). Metode penelitian pendidikan pendekatan kuantitatif, kualitatif, dan $R \& D$. Bandung: Alfabeta.

[17] Beaty, J.J. (2013). Observasi perkembangan anak usia dini. (A. Rakhman, Terjemahan). Jakarta: Kencana.

[18] Sanaky, H. (2015). Media pembelajaran interaktifinovatif. Yogyakarta: Kaukaba Dipantara. 